\title{
Adapting the Child and Youth Resilience Measure-Revised for Indonesian Contexts
}

\author{
Ihsana Sabriani Borualogo \\ Faculty of Psychology Universitas Islam Bandung, Indonesia \\ ihsana.sabriani@yahoo.com \\ Philip Jefferies \\ Resilience Research Centre Dalhousie University \\ Halifax, Nova Scotia, Canada \\ Philip.Jefferies@dal.ca
}

\begin{abstract}
This study describes the adaptation of the Child and Youth Resilience Measure-Revised (CYRM-R) for use in Indonesia. The process of adaptation involved several steps. The first step was translating and back-translating the measurement. The next step was conducting focus groups to explore the legibility of the translated measure. After this, the validity and the reliability of the translated version was tested, as well as an exploration of data. Samples were 30 elementary school children (57.7\% female) aged 10-13. Data were collected in 2 randomly chosen elementary schools in Kota Bandung. The analyses confirmed the validity and reliability of the measure (alpha $=.902)$. The results indicated that the CYRM-R had been adapted successfully and is a robust measure for exploring the social-ecological resilience of children and youth in Indonesia. The CYRM-R can be used for research and practice in the Indonesian context.
\end{abstract}

Keywords: resilience; child; measurement; cross-cultural; CYRM-R; Indonesia

Received 19April 2019/Accepted 28November 2019 @JEHCP All rights reserved

\section{Introduction}

Many Indonesians face adversity throughout their lives, occurring at many different levels, including psychological (e.g., the impact of parents divorcing, child-rearing difficulties, domestic violence, sexual violence), social (e.g., human trafficking, being bullied, poverty), and environmental (e.g., tsunamis, earthquakes). Several studies in Indonesia have explored resilience in cases of human trafficking victims (Borualogo, 2018), migrant youths (Borualogo, 20l4), rape victims (Ghina \& Suhana, 2016), and sexually abused boys (Tiarakusuma \& Rosiana, 2016). Studies from around the world have indicated the value of understanding the protective factors that help individuals to thrive and do well despite these challenges. These resilience-related qualities such as embracing cultural values and having supportive peer relationships have been found to help those at risk, such as improving the mental health of street children in Durban, South Africa (Hills, Meyer-Weitz, Asante, 2016). 
In Burundi, positive caregiving has been found to protect the well-being of children exposed to conflict (Berckmoes, de Jong, \& Reis, 2017). In Malaysia, vulnerable adolescents who had good relationships with caregivers were found to have better academic achievement (Kuldas, Hashim, Ismail, 2015). A study conducted by Wright, Talia, Aldhalimi, Broadbridge, Jamil, Lumley, Pole, Arnetz, and Arnetz (2017) revealed that kidnapped Iraqi refugee children who had better coping skills experienced lower rates of post-traumatic stress disorder.

These studies foreground the importance of exploring resilience and identifying the resources that help individuals to succeed despite adversity. However, it is important to clarify what is meant by resilience precisely, as the concept has evolved over recent decades. For instance, using an Eriksonian model of development, Grotberg (1997) defined resilience as the human capacity to face, overcome, and be strengthened by experiences of adversity. Rutter's (2012) definition is similar but emphasizes that resilience involves a reduced vulnerability to (environmental) risk experiences. One of the most inclusive definitions comes from Masten (2014), who elaborated resilience as the capacity of a dynamic system to adapt successfully to disturbances that threaten system function, viability, or development.

The definition of resilience is often bound up with its operationalization. Some researchers have moved beyond thinking of resilient as a trait. Others consider resilience as an outcome ('becoming resilient'). Others still consider resilience as a process (e.g., managing and coping with adversities) (Ungar, 20II). Ungar (2008) outlined a processual model of resilience. Ungar (2008) proposed a set of behaviours taking place over time that reflect the interactions between individuals and their environments, in particular, the opportunities for personal growth that are available and accessible. Underpinning Ungar's approach is a formula based on Lewin's theory of environment:

$$
R_{B(1,2,3 \ldots)}=\frac{f\left(P_{S C}, E\right)}{\left(O_{A C}, O_{A V}\right)(M)}
$$


In this equation, $R_{B}$ refers to resilience as a set of observable behaviors associated with adaptive outcomes in the context of adversity. $P$ refers to the person with both strengths and challenges $\left(P_{S C}\right)$.E refers to the complex ecology the person inhabits, which is not limited only to the environment. This formula draws on Bronfenbrenner's (1979) assertion of ecology as the interaction as bi-directional between person and environment. The interaction is characterized by reciprocity and not limited to a single setting. $O$ refers to opportunities, where $\mathrm{O}_{A C}$ denotes accessible opportunities, and $\mathrm{O}_{A V}$ refers to available opportunities. M refers to meaning, which determines the decisions people make regarding the resources they value and access, and which resources their family and community provide (Ungar, 20I2).

In the context of Indonesia, Ungar's theory of resilience is one that explores the process of resilience in useful ways. Resilience is understood not only from the person's perspective but also involves an understanding of the complex ecology that individuals are situated in. The interaction between person and ecology is reciprocal. This concept of reciprocity (Bronfenbrenner, 1979) is particularly resonant with the collectivist culture (Triandis, 2018). Indonesia is strongly characterized as a collectivist culture where many situations are defined by intergroup qualities. Individuals commonly think of themselves as part of one or more closely-linked collectives (family, friendship, ethnic group, nation). Individuals are willing to give priority to the goals of these collectives rather than their personal goals. Individuals also are bound together into tights groups of interdependent individuals (Triandis, 2018). Therefore, Ungar's theory of resilience is well-suited to exploring the resilience-related processes of Indonesians who see themselves strongly embedded in their collectives.

In the study of resilience, several existing measures can be used to assess the resilience of individuals and the communities they inhabit. These include the Resilience Scale (Wagnild \& Young, 1993), Connor-Davidson Resilience Scale (CD-RISC) (Connor \& Davidson, 2003), The Deployment Risk and Resilience Inventory (DRRI) (King, King, \& Vogt, 2003), Resilience Scale for Adults (RSA) (Friborg, Hjemdal, Rosenvinge, Martinussen, 2003). However, only one uses a social-ecological model of resilience, which is the Child and Youth Resilience 
Measure-Revised (CYRM-R; Jefferies, McGarrigle, \& Ungar, 2018). Therefore, to stimulate and provide the basis for contextually appropriate investigations of resilience in Indonesia, this research sought to adapt the CYRM-R. This research produces a robust tool for the measurement of resilience in Indonesian contexts, for both research and practice.

\section{Method}

\section{Design}

In this study, the CYRM-R was adapted into Indonesian through a process of translation, back-translation, piloting the legibility of the translated scale, and focus group discussions regarding the translation (van de Vijver \& Hambleton, 1996; van de Vijver, 2015). Backtranslation is a validation tool widely used in international research settings, including crosscultural psychology considering the context (Brislin, 1970; Cha, Kim, \& Erlen, 2007; Lee, Li, Arai, \& Puntillo, 2009; Prieto, 1992; Sidani, Guruge, Miranda, Ford-Gilboe, \& Varcoe, 2010; Tyupa, 20II)

The back-translation technique is one of the most popular methods to assess the quality of translation and to ensure the construct validity of the measures (Tyupa, 20II; van de Vijver, 2015; van de Vijver \& Hambleton, 1996). To adapt the CYRM-R into the Indonesian context, we used the back-translating technique following van de Vijver (2015) and van de Vijver and Hambleton (1996) as explained in the procedure section below.

We also tested the validity and reliability of the measure using Pearson's product-moment and Cronbach's alpha.

\section{Sample}

Data was obtained from piloting the translated measure in two randomly chosen elementary schools in Kota Bandung, West Java, Indonesia. The participants were 130 elementary students aged I0-13 years-old (Table I). 
Table I

Sample Characteristics

\begin{tabular}{lccccc}
\hline & \multicolumn{5}{c}{ Age } \\
\hline Boys & 10 & 11 & 12 & 13 & Total \\
Girls & 30 & 18 & 6 & 1 & 55 \\
Total & 45 & 17 & 13 & 0 & 75 \\
\hline
\end{tabular}

\section{Ethical clearance}

Approval for the study was gained from the ethical committee in UniversitasPadjadjaran (www.kepk.fk.unpad.ac.id). Permission to conduct the research in Kota Bandung was obtained from Badan Kesatuan Bangsa dan Politik (Institution of National Unity and Politics) and the Ministry of Education in the district level of Kota Bandung, West Java, Indonesia. The elementary schools which were randomly chosen for the study were contacted and agreed to participate. Written consent from parents was obtained on behalf of the children. The children themselves were informed that they were free not to answer the questions and that their data would be treated confidentially.

\section{The measure}

The child and Youth Resilience Measure (CYRM) is a tool that provides indications of an individual's social-ecological resilience. The CYRM-R scores on the measure reflect their ability to engage with external resources to manage adversity. It was originally developed using data from the International Resilience Project, involving I4 communities across II countries (Ungar, 2006; 20II). It has since been translated into more than 20 languages and used in more than 150 research studies (Jefferies, Vanstone, \& Ungar, in press; Resilience Research Centre, 2016). The psychometric properties of the measure have also been tested and it has been found to be appropriate for use with cultures around the world (Daigneault, Dion, Hebert, McDuff, Collin-Vezina, 2013; Sanders, Munford, Thimasarn-Anwar, Liebenberg, 2017; Panter-Brick, Hadfield, Dajani, Eggerman, Ager, Ungar, 2018; van Rensburg, Theron, Ungar, 2019). 
Since its original development, the CYRM has undergone some changes, including being developed into a version for young children (the CYRM-R child version) and a version for adults (the Adult Resilience Measure). The current version of the CYRM is the CYRM-R (Child and Youth Resilience Measure-Revised; Jefferies et al., 2018), which is aimed at individuals aged 10-23. This CYRM-R (Jefferies et al., 2018) is the version of the measure that we adapted, which uses a 5-point Likert scale (from I = Not at all/Tidak sama sekal; 2 = A little/Jarang; 3 = Somewhat/Kadang-kadang; 4 = Quite a bit/Agak sering; to $5=\mathrm{A}$ lot/Sering)

The CYRM-R consists of a base set of 17 items that measure personal resilience (e.g., "I know how to behave/act in different situations", "I have chances to show others that I am growing up and can do things by myself") and caregiver/relational resilience (e.g., "My parents/caregivers really look out for me"). The items in the measure are all positivelyworded (no reverse scoring), so scoring involves simple summing of responses, where higher scores indicate characteristics associated with stronger resilience (Resilience Research Centre, 2018).

\section{Procedure}

Several stages were involved in the process of adapting the CYRM-R. We followed the guidance of van de Vijverand Hambleton (1996) and van de Vijver (20I5), who recommend a conceptual translation process, a back-translation, piloting the legibility of the translated scale, and a focus group discussion regarding participant understanding.

To avoid poor item translation and inadequate conceptual formulation (van de Vijver \& Poortinga, 1997; van de Vijver \& Leung, 20II), the translation team first learned the 'blueprint' of the CYRM-R, carefully reading and discussing each item and the subscales to understand what the original authors intended (Resilience Research Centre, 2018). The items were then translated into the national Indonesian language (Bahasa Indonesia), taking into account the purpose of each item, the context of Indonesia, and the characteristics of Indonesian children, including their level of understanding, thereby minimizing the chance of problems relating to literal/direct translation. 
In the process of translating the measure, short and simple sentences were used that could be easily understood by Indonesian children. An active voice was used in the phrasing of the items for further clarity. The instructions and response options for the measure were also carefully translated to keep the same meaning.

The measure was then back-translated from Indonesian to English. This back-translating is a technique where a second translator (not familiar with the instrument) translates the material back into the original language (van de Vijver \& Hambleton, 1996; van de Vijver, 20I5). We requested an English professional editor who was not familiar with the CYRM-R to undertake this. After receiving the back-translated version, we compared this to the original version to check for any conceptual differences.

Once the draft translation was completed, we tested it with 130 elementary students to check the understandability of the instructions, the wording of the items, and the amount of time needed to answer the measure. This involved two elementary schools, with three classes in each: grade 4 (age I0-II), grade 5 (age II-I2), and grade 6 (age I2-I3). In each class, there were about 20-22 children.

One of two research assistants read aloud the instructions while the students read along on a paper version. The students were then instructed to fill in the CYRM-R individually while the assistants observed the process. Following this, the assistants began focus group discussions, where the students were asked about the meaning of each item and the wording. Problematic items were then adjusted to ensure accurate comprehension and reread to the whole class. The participants rescored any adjusted items based on their new understanding, and their responses to the measure were collected for analysis.

\section{Data analysis}

We reviewed data collected using the adapted measure, checking the proportion of missing responses. If more than $10 \%$ of missing data were detected, this could suggest issues for participants using the measure and lead to bias if it were to be involved in further research 
(Dong \& Peng 2013). Further, if participants appeared to skip or miss particular items, this could be indicative of issues such as a lack of comprehension or that they were not willing to engage them.

We then explored differences between the sexes using independent samples t-tests. These were applied to each subscale/domain of the measure as well as overall scores, to ensure similarity between subgroups. Finally, we sought to visually inspect distributions of scores on the measure and individual items between sexes, in order to ensure approximate equivalence.

Back-translation is a standard method for adapting measurements in the cross-cultural psychology approach (Tyupa, 20II; van de Vijver, 20I5; van de Vijver \& Hambleton, 1996). The results of the validity of the back-translation method can be found by comparing similarities between the original version and the back-translated version. We also tested the validity and reliability of the measurement using Pearson's product-moment and Cronbach's alpha, as presented in the results section below.

\section{Results}

Following translation and back-translation, a comparison of the original and Indonesian versions revealed no meaningful conceptual dissimilarities (Table 2). This supports the construct validity of the translated version of the measure. Following the pilot of the translated measure with the children, the research assistants found that the measure required approximately 20 minutes to complete.

The focus groups indicated good comprehension of the instructions and response categories, though there were minor issues with some of the items. For item number 14, which asks about growing up, the children understood the initial translation of this item as being about becoming an adult. The children suggested this was slightly confusing as they felt they were not going to be adults soon. The assistants explained the meaning of growing up and the intention to explore maturation, and it was suggested that the wording be changed to "growing bigger" for clarity. Another suggestion was to change the wording "older" in 
item number 16, which the children felt meant getting old (elderly). Therefore, the wording was changed to "grow up as an adult one day."The final translation the participants responded to is given in Table 2 .

Table 2

Original English and Indonesian versions of the CYRM-R

\begin{tabular}{|c|c|c|c|}
\hline Item & English original version & Bahasa Indonesia translation & English back translation \\
\hline- & $\begin{array}{l}\text { To what extent do the } \\
\text { following statements apply } \\
\text { to you? } \\
\text { There are no right or } \\
\text { wrong answers. }\end{array}$ & $\begin{array}{l}\text { Berikut ini adalah daftar } \\
\text { pernyataan mengenai bagaimana } \\
\text { kamu menilai dirimu dan orang di } \\
\text { sekitarmu. } \\
\text { Bagaimanakah pernyataan- } \\
\text { pernyataan ini sesuai dengan } \\
\text { keadaanmu? } \\
\text { Tidak ada jawaban yang benar atau } \\
\text { salah. }\end{array}$ & $\begin{array}{l}\text { Choose the best answer } \\
\text { according to your condition. } \\
\text { There is no right or wrong } \\
\text { answer. }\end{array}$ \\
\hline 1 & $\begin{array}{l}\text { I get along with people } \\
\text { around me }\end{array}$ & $\begin{array}{l}\text { Saya akur dengan orang-orang di } \\
\text { sekitar saya }\end{array}$ & $\begin{array}{l}\text { I get along with people around } \\
\text { me }\end{array}$ \\
\hline 2 & $\begin{array}{l}\text { Getting an education is } \\
\text { important to me }\end{array}$ & $\begin{array}{l}\text { Mendapatkan pendidikan adalah } \\
\text { penting bagi saya }\end{array}$ & $\begin{array}{l}\text { Getting education is important } \\
\text { for me }\end{array}$ \\
\hline 3 & $\begin{array}{l}\text { I know how to behave/act } \\
\text { in different situations (such } \\
\text { as school, home, and } \\
\text { church) }\end{array}$ & $\begin{array}{l}\text { Saya tahu bagaimana harus } \\
\text { berperilaku dalam berbagai situasi } \\
\text { berbeda (seperti di sekolah, di } \\
\text { rumah, dan tempat ibadah, seperti } \\
\text { masjid, gereja) }\end{array}$ & $\begin{array}{l}\text { I know how to behave in any } \\
\text { different situation (such as in } \\
\text { school, in my house, and places } \\
\text { of worship, like mosque, } \\
\text { church) }\end{array}$ \\
\hline 4 & $\begin{array}{l}\text { My parent(s)/caregiver(s) } \\
\text { really look out for me }\end{array}$ & $\begin{array}{l}\text { Orang tua saya sangat } \\
\text { memperhatikan saya }\end{array}$ & $\begin{array}{l}\text { My parents are very attentive } \\
\text { to me }\end{array}$ \\
\hline 5 & $\begin{array}{l}\text { My parent(s)/caregiver(s) } \\
\text { know a lot about me (for } \\
\text { example, who my friends } \\
\text { are, what I like to do) }\end{array}$ & $\begin{array}{l}\text { Orang tua saya mengetahui banyak } \\
\text { hal mengenai saya (sebagai contoh, } \\
\text { siapa teman-teman saya, apa yang } \\
\text { saya sukai) }\end{array}$ & $\begin{array}{l}\text { My parents know a lot of } \\
\text { things about me (for example, } \\
\text { who my friends are, what I } \\
\text { like) }\end{array}$ \\
\hline 6 & $\begin{array}{l}\text { If I am hungry, there is } \\
\text { enough to eat }\end{array}$ & $\begin{array}{l}\text { Ketika saya lapar, tersedia cukup } \\
\text { makanan untuk saya makan }\end{array}$ & $\begin{array}{l}\text { When I am hungry, there is } \\
\text { enough food for me to eat }\end{array}$ \\
\hline 7 & $\begin{array}{l}\text { People like to spend time } \\
\text { with me }\end{array}$ & $\begin{array}{l}\text { Orang-orang senang menghabiskan } \\
\text { waktu bersama saya }\end{array}$ & $\begin{array}{l}\text { People like to spend time with } \\
\text { me }\end{array}$ \\
\hline 8 & $\begin{array}{l}\text { I talk to my } \\
\text { family/caregiver(s) about } \\
\text { how I feel (for example } \\
\text { when I am hurt or sad) }\end{array}$ & $\begin{array}{l}\text { Saya berbicara kepada } \\
\text { keluarga/orang tua saya mengenai } \\
\text { perasaan saya (sebagai contoh, } \\
\text { ketika saya sedang sedih atau sakit } \\
\text { hati) }\end{array}$ & $\begin{array}{l}\text { I speak with my family/parents } \\
\text { about how I feel (for example, } \\
\text { when I am sad or my heart } \\
\text { aches) }\end{array}$ \\
\hline 9 & $\begin{array}{l}\text { I feel supported by my } \\
\text { friends }\end{array}$ & $\begin{array}{l}\text { Saya merasa didukung oleh teman- } \\
\text { teman saya }\end{array}$ & I feel supported by my friends \\
\hline
\end{tabular}




\begin{tabular}{|c|c|c|c|}
\hline 10 & $\begin{array}{l}\text { I feel that I belong/belonged } \\
\text { at my school }\end{array}$ & $\begin{array}{l}\text { Saya merasa menjadi bagian dari } \\
\text { sekolah saya }\end{array}$ & I feel a part of my school \\
\hline II & $\begin{array}{l}\text { My family/caregiver(s) care } \\
\text { about me when times are } \\
\text { hard (for example if I am } \\
\text { sick or have done } \\
\text { something wrong) }\end{array}$ & $\begin{array}{l}\text { Keluarga/orang tua saya peduli } \\
\text { terhadap saya ketika saya berada } \\
\text { dalam masa-masa sulit (sebagai } \\
\text { contoh, ketika saya sakit atau telah } \\
\text { melakukan suatu kesalahan) }\end{array}$ & $\begin{array}{l}\text { My family/parents care about } \\
\text { me when I have a hard time } \\
\text { (for example, when I am sick } \\
\text { or have made a mistake) }\end{array}$ \\
\hline 12 & $\begin{array}{l}\text { My friends care about me } \\
\text { when times hard (for } \\
\text { example if I am sick or have } \\
\text { done something wrong) }\end{array}$ & $\begin{array}{l}\text { Teman-teman saya peduli terhadap } \\
\text { saya ketika saya berada dalam } \\
\text { masa-masa sulit (sebagai contoh, } \\
\text { ketika saya sakit atau telah } \\
\text { melakukan suatu kesalahan) }\end{array}$ & $\begin{array}{l}\text { My friends care for me when I } \\
\text { have a hard time (for example, } \\
\text { when I am sick or have made a } \\
\text { mistake) }\end{array}$ \\
\hline 13 & $\begin{array}{l}\text { I am treated fairly in my } \\
\text { community }\end{array}$ & $\begin{array}{l}\text { Saya diperlakukan dengan adil di } \\
\text { lingkungan saya }\end{array}$ & $\begin{array}{l}\text { I am treated fairly in my } \\
\text { environment }\end{array}$ \\
\hline 14 & $\begin{array}{l}\text { I have chances to show } \\
\text { others that I am growing up } \\
\text { and can do things by myself }\end{array}$ & $\begin{array}{l}\text { Saya memiliki banyak kesempatan } \\
\text { untuk menunjukkan kepada orang } \\
\text { lain bahwa saya tumbuh menjadi } \\
\text { lebih besar dan dapat melakukan } \\
\text { banyak hal sendirian }\end{array}$ & $\begin{array}{l}\text { I have a lot of chances to show } \\
\text { other people that I grow bigger } \\
\text { and can do many things on my } \\
\text { own }\end{array}$ \\
\hline 15 & $\begin{array}{l}\text { I feel safe when I am with } \\
\text { my family/caregiver(s) }\end{array}$ & $\begin{array}{l}\text { Saya merasa aman ketika saya } \\
\text { bersama orang tua / keluarga saya }\end{array}$ & $\begin{array}{l}\text { I feel safe when I am with my } \\
\text { parents/family }\end{array}$ \\
\hline 16 & $\begin{array}{l}\text { I have chances to learn } \\
\text { things that will be useful } \\
\text { when I am older (like } \\
\text { cooking, working, and } \\
\text { helping others) }\end{array}$ & $\begin{array}{l}\text { Saya memiliki banyak kesempatan } \\
\text { untuk mempelajari banyak hal yang } \\
\text { akan berguna ketika saya dewasa } \\
\text { nanti (seperti, memasak, bekerja, } \\
\text { dan menolong orang lain) }\end{array}$ & $\begin{array}{l}\text { I have a lot of opportunities to } \\
\text { study many things that will } \\
\text { benefit me when I grow up as } \\
\text { an adult one day (Such as } \\
\text { cooking, working, and helping } \\
\text { others) }\end{array}$ \\
\hline 17 & $\begin{array}{l}\text { I like the way my } \\
\text { family/caregiver(s) } \\
\text { celebrates things (like } \\
\text { holidays or learning about } \\
\text { my culture) }\end{array}$ & $\begin{array}{l}\text { Saya menyukai cara } \\
\text { keluarga/orang tua saya merayakan } \\
\text { berbagai hal (seperti, liburan atau } \\
\text { belajar mengenai budaya saya) }\end{array}$ & $\begin{array}{l}\text { I like how my family/parents } \\
\text { celebrate my things (such as } \\
\text { vacation, or learning about my } \\
\text { culture) }\end{array}$ \\
\hline
\end{tabular}

Analyses of participant responses indicated that there were fewer than $1 \%$ missing responses to the measure, suggesting that the children understood and were willing to answer each of the items. This also suggests the back-translated version had good construct validity. 


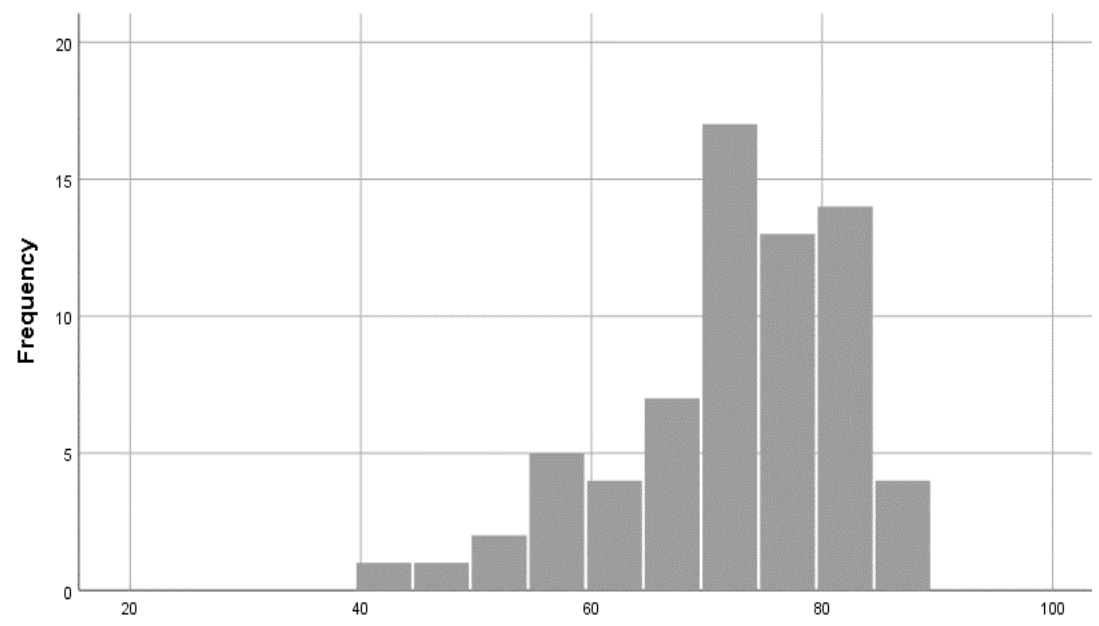

Figure I. Frequency of overall CYRM-R scores by gender (girls)

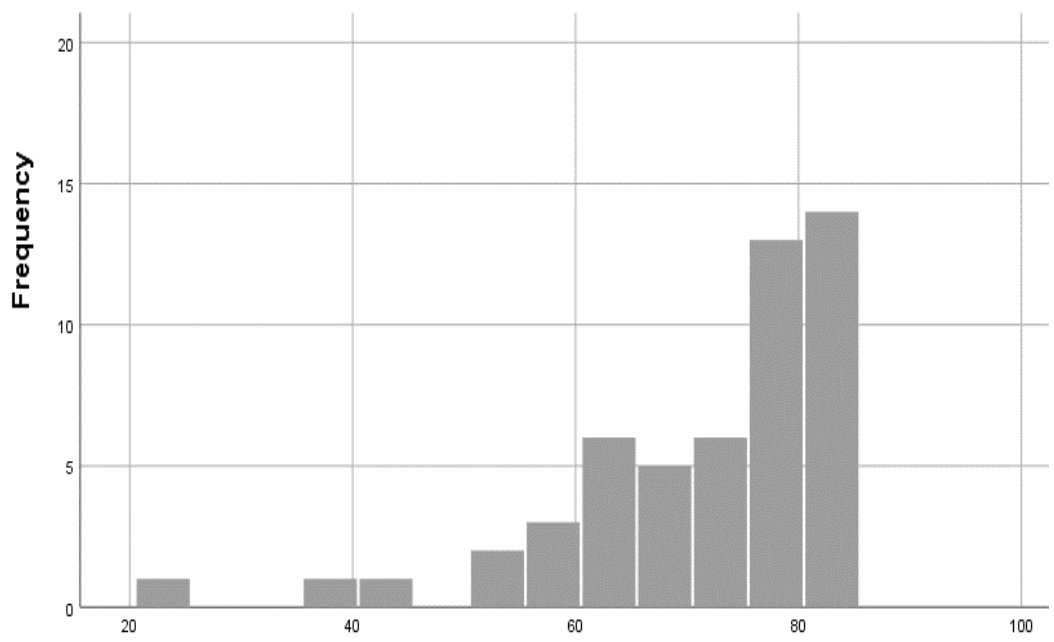

Figure 2.Frequency of overall CYRM-R scores by gender (boys)

The histograms in Figures I and 2 illustrate the frequency of overall scores on the measure. These distributions are slightly negatively skewed, but this is expected on a measure like the CYRM-R where the majority of a general sample is anticipated to be somewhat resilient. Although these distributions suggest that boys tend to have higher scores than girls, independent t-tests revealed that neither the overall scores nor any of the subscales or domains of the measure significantly differed between the sexes ( $p>.05$ ) (Table 3). In other words, girls and boys tend to score about the same, which accords with extant results in the literature (Jefferies et al., 20l8). 
Table 3

Pilot Scores on the Measure (Mean and Standard Deviation)

\begin{tabular}{lccc}
\hline CYRM-R score & Boys & Girls & Total \\
\hline Overall resilience & $7 \mathrm{I} .8 \mathrm{I}(\mathrm{I} 2.85)$ & $7 \mathrm{I} .99(9.70)$ & $7 \mathrm{I} .9 \mathrm{I}(\mathrm{II} .12)$ \\
Personal/Intrapersonal subscale & $4 \mathrm{I} .74(8.1 \mathrm{I})$ & $4 \mathrm{I} .69(6.13)$ & $4 \mathrm{I} .7 \mathrm{I}(7.02)$ \\
Caregiver/Relational subscale & $29.87(5.39)$ & $30.22(3.97)$ & $30.07(4.6 \mathrm{I})$ \\
Individual domain & $29.02(5.73)$ & $28.67(4.29)$ & $28.82(4.93)$ \\
Relational domain & $29.87(5.39)$ & $30.22(3.97)$ & $30.07(4.6 \mathrm{I})$ \\
Contextual domain & $12.69(2.64)$ & $13.05(2.23)$ & $12.90(2.4 \mathrm{I})$ \\
\hline
\end{tabular}

Note: All differences between boys and girls are non-significant.

Personal/interpersonal subscale $=$ items number $4,5,6,1 \mathrm{I}, 15,17$.

Caregiver/Relational subscale $=$ items number $1,2,3,7,9,10,12,13,14,16$

Individual domain $=$ items number $1,3,7,9,12,14,16$.

Relational domain $=$ items number $4,5,6,8,11,15,17$

Contextual domain $=$ items number $2,10,13$.

There was a little variation in the average of individual item scores between the sexes (Figure 3), and between average item scores for each sex. Boys appeared to score lowest on item 4 (My parent(s)/caregiver(s) really look out for me) and 10 (I feel I belong/belonged at my school), while girls scored lowest on item 8 (I talk to my family/caregiver(s) about how I feel). Girls were scored highest on item I5 (I feel safe when I am with my family/caregiver) while boys scored highest on items 3 (I know how to behave/act in different situations (such as school, home, and church)) and 16 (I have chances to learn things that will be useful when I am older (like cooking, working, and helping others)). However, these were minor differences compared to the other items. 


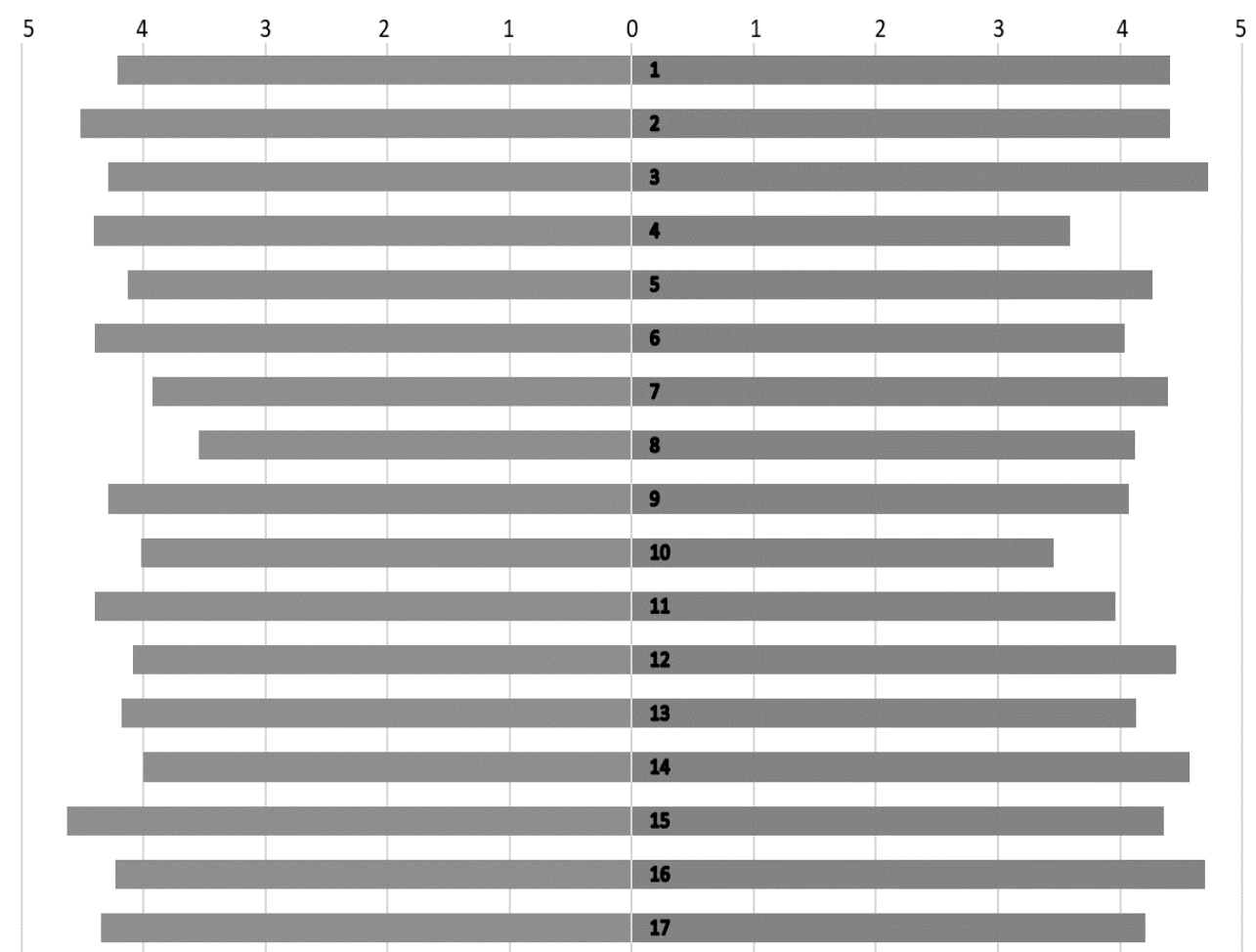

Figure 3. Bi-directional graph showing average responses to each item in the measure (girls: left; boys: right).

The results of the correlation analysis indicated that all items shared significant and strong positive correlation $(p<.00 \mathrm{I})$ with the overall score (Table 4$)$.

Table 4

Validity score of items of CYRM-R

\begin{tabular}{llr}
\hline No. item & & Total Score \\
\hline 1 & Pearson Correlation & $.613^{* *}$ \\
& Sig. (2-tailed) & .000 \\
2 & Pearson Correlation & $.564^{* *}$ \\
& Sig. (2-tailed) & .000 \\
3 & Pearson Correlation & $.483^{* *}$ \\
& Sig. (2-tailed) & .000 \\
4 & Pearson Correlation & $.658^{* *}$ \\
& Sig. (2-tailed) & .000 \\
5 & Pearson Correlation & $.576 * *$ \\
& Sig. (2-tailed) & .000 \\
6 & Pearson Correlation & $.656 * *$ \\
\hline
\end{tabular}




\begin{tabular}{|c|c|c|}
\hline No. item & & Total Score \\
\hline & Sig. (2-tailed) & .000 \\
\hline \multirow[t]{2}{*}{7} & Pearson Correlation & $.548 * *$ \\
\hline & Sig. (2-tailed) & .000 \\
\hline \multirow[t]{2}{*}{8} & Pearson Correlation & $.532 * *$ \\
\hline & Sig. (2-tailed) & .000 \\
\hline \multirow[t]{2}{*}{9} & Pearson Correlation & $.647 * *$ \\
\hline & Sig. (2-tailed) & .000 \\
\hline \multirow[t]{2}{*}{10} & Pearson Correlation & $.666^{* *}$ \\
\hline & Sig. (2-tailed) & .000 \\
\hline \multirow[t]{2}{*}{ II } & Pearson Correlation & $.663^{* *}$ \\
\hline & Sig. (2-tailed) & .000 \\
\hline \multirow[t]{2}{*}{12} & Pearson Correlation & $.655^{* *}$ \\
\hline & Sig. (2-tailed) & .000 \\
\hline \multirow[t]{2}{*}{13} & Pearson Correlation & $.70 I^{* *}$ \\
\hline & Sig. (2-tailed) & .000 \\
\hline \multirow[t]{2}{*}{14} & Pearson Correlation & $.578 * *$ \\
\hline & Sig. (2-tailed) & .000 \\
\hline \multirow[t]{2}{*}{15} & Pearson Correlation & $.54 I^{* *}$ \\
\hline & Sig. (2-tailed) & .000 \\
\hline \multirow[t]{2}{*}{16} & Pearson Correlation & $.660 * *$ \\
\hline & Sig. (2-tailed) & .000 \\
\hline \multirow[t]{2}{*}{17} & Pearson Correlation & $.605^{* *}$ \\
\hline & Sig. (2-tailed) & .000 \\
\hline
\end{tabular}

The reliability test (Table 5) indicated that the CYRM-R in the Indonesian context after following the procedure of the back-translation method in the context of cross-cultural psychology was strongly reliable (alpha $=.902)$.

Table 5

Reliability test of CYRM-R

\begin{tabular}{ll}
\hline Cronbach's Alpha & Number of items \\
\hline .902 & 17 \\
\hline
\end{tabular}




\section{Discussion}

Research on resilience in Indonesia has been increasing over the decades. Resilience using the social ecological approach (Ungar, 2012) is suited to Indonesian contexts and can be measured using an adapted version of the CYRM-R.

Back-translation is a cross-cultural psychology method that can help to ensure the construct validity of adapted measures. The back-translation technique compares the similarities between the original and the back-translated version(Tyupa, 20II; van de Vijver, 20I5; van de Vijver \& Hambleton, 1996). This method was used in this study, considering the Indonesian context since the original version of the measure was in English. The results showed there were no dissimilarities between the original version and the back-translated version. Therefore, the measure appeared to have good construct validity.

The CYRM-R has been successfully adapted for use in Indonesian contexts, ensuring a robust means of measuring resilience in Indonesian children and youth. Since this Indonesian CYRM-Rusesthe national language of Bahasa Indonesia, it can be used throughout the country.

The Indonesian CYRM-R can be used by researchers and practitioners to gauge levels of social-ecological resilience in Indonesian children and youth. This is important for understanding how young people can overcome adversity and achieve positive outcomes (e.g., Katisi, Jefferies, Dikolobe, Moeti, Brisson, \& Ungar, 2019). Applications of the measure can help to identify areas where resilience resources may be lacking, and therefore where to invest in improving the likelihood of good outcomes. Through the use of the CYRM-R, in conjunction with appropriate tools to measure risk, researchers can also determine appropriate intervention options for vulnerable and at-risk individuals in Indonesia (Ungar, 2017).

One limitation of this study is that the process of translation only involved elementary students who could be considered a 'healthy' sample. It remains to be seen how the measure will perform in a group of at-risk or vulnerable children and youth (e.g., children and youth being bullied, those with mental health difficulties or living in poverty, etc). 
Therefore, an important avenue of future inquiry is to examine how the measure performs with such a sample.

\section{Conclusion}

The CYRM-R has been adapted successfully into Indonesian and can be used for research and practice in Indonesian contexts. This provides the basis for measuring and studying the social-ecological resilience of children and youth in Indonesia, and therefore the means to identify how to help young people do well despite the challenges they face.

\section{Acknowledgments}

This pilot study was funded by the Faculty of Psychology Universitas Islam Bandung.

\section{References}

Bennett, K.M., Reyes-Rodriguez, M.F., Altamar, P. (2016). Resilience amongst older Colombians living in poverty: An ecological approach. Journal of Cross-Cultural Gerontology, 3 I (4), 385-407.

Berckmoes, L.H., de Jong, J.T.V.M., \& Reis, R. (2017). Intergenerational transmission of violence and resilience in conflict-affected Burundi: A qualitative study of why some children thrive despite duress. Global Mental Health, 4(26), I-I 2.

Borualogo, I.S. (20I4). Pengaruh nilai budaya merantau, system nilai, dan dukungan sosial yang dimediasi harga diri terhadap kepegasan sebagai penentu kepuasan akan hidup suatu studi Psikologi Lintas Budaya pada mahasiswa perantau etnik Batak, Minang, dan Sunda di Bandung. Disertation. Universitas Padjadjaran.

Borualogo, I.S. (20I8). Resilience on human trafficking victims in West Java. MimbarjurnalSosialdan Pembangunan, 34(I), 204-2 12.

Brislin, R.W. (1970). Back-translation for cross-cultural research. Journal of Cross-Cultural Psychology, I(3), I85-2 I6. http://dx.doi.org/I0.1 I77//359/045700010030 I

Bronfenbrenner, U. (1979). The ecology of human development: experiment by nature and design. USA: Harvard University Press.

Cha, E.S., Kim, K.H., \&Erlen, J.A. Translation of scales in cross-cultural research: issues and techniques. Journal of Advanced Nursing, 58(4), 386-395.

Connor, K.M., \& Davidson, J.R.T. (2003). Development of a new resilience scale: The Connor-Davidson Resilience Scale (CD-RISC). Depression and Anxiety, 18, 76-82. 
Daigneault, I., Dion, J., Hebert, M., McDuff, P., Collin-Vezina, D. (2013). Psychometric properties of the Child and Youth Resilience Measure (CYRM-28) among samples of French Canadian youth. Child Abuse and Neglect. 37(2), I60-I7I.

Dong, Y., \& Peng, C-Y.J. (20|3). Principled missing data methods for researchers. SpringerPlus, 2, 222. DOI: 10.1186/2193-1801-2-222

Fletcher, D. \& Sarkar, M. (20|3). Psychological resilience: A review and critique of definitions, concepts, and theory. European Psychologist. I8(I), 12-23. Doi: I0.1027/I0169040/a000I24

Friborg, O., Hjemdal, O., Rosenvinge, J.H., \& Martinussen, M. (2003). A new rating scale for adult resilience: what are the central protective resources behind healthy adjustment? International Journal of Methods in Psychiatric Research, I2(2), 65-76.

Ghina, S., \& Suhana, S. (2016). Studi deskriptif mengenai resiliensi remaja korban pemerkosaan di Kabupaten Cirebon. Spesia Proceeding. Retrieved from repository.unisba.ac.id:8080/xmlui/handle/I23456789//2664.

Grotberg, E.H. (1997). The International Resilience Research Project. Paper presented at the Annual Convention of the International Council of Psychologists. Retrieved from https://files.eric.ed.gov/fulltext/ED4|786I.pdf

Hills, F., Meyer-Weitz, A., \& Asante, K.O. (2016). The lived experiences of street children in Durban, South Africa: Violence, substance use, and resilience. International Journal of Qualitative Studies on Health and Well-Being, I I.DOI: 10.3402/qhw.v I I.30302.

Jefferies, P., McGarrigle, L., \& Ungar, M. (2018). The CYRM-R: a Rasch-validated revision of the Child and Youth Resilience Measure. Journal of Evidence-Informed Social Work, I-24. https://doi.org//0.1080/2376|407.2018.1548403.

Jefferies, P., Vanstone, R., \& Ungar, M. (in press). Measuring social-ecological resilience: a decade of research with the Child and Youth Resilience Measure and the Adult Resilience Measure. In Resilience in Children, Adolescents, and Adults (vol.3). S. Prince-Embury and S. Saklofske (Eds.). New York, NY: Springer.

Jordanova-Peshevska, D., \& Tozija, F. (2018). Are resiliency factors increasing the risk for childhood psychological victimization?. Open Access Macedonian Journal of Medical Science, 6(6), II68-II73.

Katisi, M., Jefferies, P., Dikolobe, O., Moeti, O., Brisson, J., \& Ungar, M. (2019). Fostering resilience in children who have been orphaned: preliminary results from the Botswana Balekane EARTH program. Child Youth Care Forum. https://doi.org/I0.1007/sI0566-01909497-6.

King, D.W., King, L.A., \& Vogt, D.S. (2003). The Deployment Risk and Resilience Inventory (DRRI). National Center for PTSD.

Kuldas, S., Hashim, S., \&lsmail, H.N. (2015). Malaysian adolescent students' need for enhancing thinking skills, counteracting risk factors and demonstrating academic resilience. International Journal of Adolescence and Youth, 20(I), 32-47.

Lee, C.C., Li, D., Arai, S., Puntillo, K. (2009). Ensuring cross-cultural equivalence in the translation of research consents and clinical documents: A systematic process for translating English to Chinese. Journal of Transcultural Nursing, 20(I), 77-82 
Luthar, S., \& Cicchetti, D. (2000). The construct of resilience: Implications for interventions and social policies. Developmental Psychology, I2(4), 857-885.

Masten, A. (20I4). Ordinary magic: Resilience in development. NY: The Guilford Press.

Panter-Brick, C., Hadfield, K., Dajani, R., Eggerman, M., Ager, A., \& Ungar, M. (2018). Resilience in context: A brief and culturally grounded measure for Syrian refugee and Jordanian host-community adolescents. Child Development, 89(5), 1803-1820.

Resilience Research Centre. (2016). The Child and Youth Measure (CYRM) Child Version user manual. Halifax, NS: Resilience Research Centre, Dalhousie University. Retrieved from http://www.resilienceresearch.org

Resilience Research Centre. (2018). CYRM and ARM user manual. Halifax, NS: Resilience Research Centre, Dalhousie University. Retrieved from http://www.resilienceresearch.org.

Rutter, M. (2012). Resilience as a dynamic concept. Development and Psychopathology, 24, 335-344.

Prieto, A.J. (1992). A method for translation of instruments to other languages. Adult Education Quarterly, 43(I), I-I4.

Sanders, J., Munford, R., Thimasarn-Anwar, T., \& Liebenberg, L. (2017). Validation of the Child and Youth Resilience Measure (CYRM-28) on a sample of at-risk New Zealand youth. Research on Social Work Practice. 27(7), 827-840.

Sidani, S., Guruge, S., Miranda, J., Ford-Gilboe, M., \& Varcoe, C. (2010). Cultural adaptation and translation of measures: An integrated method. Research in Nursing and Health, $33(2), 133-143$.

Tiarakusuma, C., \&Rosiana, D. (2016). Studi deskriptif mengenai resiliensi pada anak laki-laki korban pelecehan seksual. Spesia Proceeding. Retrieved from repository.unisba.ac.id:8080/xmlui/handle/I23456789//27I9.

Triandis, H.C. (2018). Individualism and collectivism. USA: Routledge.

Tyupa, S. (20I I). A theoretical framework for back-translation as a quality assessment tool. New Voices in Translation Studies, 7, 35-46.

Wessells, M.G., (2016). Strengths-based community action as a source of resilience for children affected by armed conflict. Global Mental Health, 3(I), I-5.

Ungar M. (2006). Nurturing hidden resilience in at-risk youth in different cultures. Journal of the Canadian Academy of Child and Adolescent Psychiatry, I 5(2), 53-58.

Ungar, M. (2008). Resilience across culture. British Journal of Social Work, 38, 218-235.

Ungar, M. (20II). The social ecology of resilience: Addressing contextual and cultural ambiguity of a nascent construct. American Journal of Orthopsychiatry, 8I(I), I-I7.

Ungar, M. (20I2). Social ecologies and their contribution to resilience. In M.Ungar (Ed.). The social ecology of resilience $-A$ handbook of theory and practice. Dordrecht: Springer. Pp. I331 . 
Ungar, M. (2017). Which counts more: Differential impact of the environment or differential susceptibility of the individual? British Journal of Social Work, 47, 1279-1289. Doi: 10.1093/bjsw/bcwl09.

Ungar, M., \& Liebenberg, L. (20II). Assessing resilience across cultures using mixed methods: Construction of the child and youth resilience measure. Journal of Mixed Methods Research. 5(2), I26-I49. Doi: 10.1 I77//5586898I I 400607.

van de Vijver, F.J.R. (20I5). Methodological aspects of cross-cultural research. In M. Gelfand, Y. Hong, \& C.Y. Chiu (Eds.), Handbook of advances in culture \& psychology (Vol. 5, PP. I0I-160). New York: Oxford University Press.

van de Vijver, F.J.R., \& Hambleton, R.K. (1996) Translating Tests: Some Practical Guidelines. EuropeanPsychologist, I(2), 88-99.

van de Vijver, F.J.R., \& Leung, K. (20II). Equivalence and bias: A review of concepts, models, and analytic data procedures, cross-cultural researchmethodology in Psychology. USA: Cambridge UniversityPress.

van de Vijver, F.J.R., \& Poortinga, Y. (1997). Towards an integrated analysis of bias in crosscultural assessment. European Journal of Psychological Assessment, I3(I), 29-37.

vanRensburg, A.C., Theron, L.C., \& Ungar, M. (2019). Using the CYRM-28 with South African young people: a factor structure analysis. Research on Social Work Practice. 29(1), 93-102.

Wagnild G. (2009). A review of the Resilience Scale. J Nurs Meas, I 7(2), I05-I I 3.

Wright, A.M., Talia, Y.R., Aldhalimi, A., Broadbridge, C.L., Jamil. H., Lumley, M.A., Pole, N., Arnetz, B.B., \& Arnetz, J.E. (2017). Kidnapping and mental health in IraqiRefugees:Therole of resilience. Journal of Immigrant and MinorityHealth, 19(I), 98107. 